\title{
Protocol
}

\section{Simple Multiplexed Antibody-Binding Assay}

\author{
Thomas D. Duensing and Susan R. Watson
}

This simple protocol tests antibody binding to target antigens on the surface of cells. This assay is powerful because negative controls are built into each well of the screening plates. It can be used to screen crude supernatants from hybridomas, as well as bacterial periplasmic extracts when screening phage libraries. Using cell-permeant dyes allows the negative and positive cell lines to be color-coded and screened in the same well. A variant enzyme-linked immunosorbent assay can be performed where the target antigen is presented on beads.

\section{MATERIALS}

It is essential that you consult the appropriate Material Safety Data Sheets and your institution's Environmental Health and Safety Office for proper handling of equipment and hazardous material used in this protocol.

RECIPES: Please see the end of this protocol for recipes indicated by $<R>$. Additional recipes can be found online at http://cshprotocols.cshlp.org/site/recipes.

Cell line (or bead) presenting the target of interest

Cell-permeant dye (e.g., CellTrace CFSE [carboxyfluorescein succinimidyl ester] or Violet; ThermoFisher Scientific)

Prepare stock solutions according to the manufacturer's instructions.

Fetal bovine serum (FBS)

Fluorescence-activated cell sorting (FACS) buffer $<\mathrm{R}>$

Hybridoma supernatant (optional; see Step 6)

Mouse anti-c-myc or other appropriate tag for detecting phage binding (optional; see Step 6)

Phage-expressing antibodies often are engineered to express an epitope tag. In most cases, epitope tags are constructed of amino acids and are added to a molecule (usually proteins) that an investigator wants to visualize. Although any short stretch of amino acids known to bind an antibody could become an epitope tag, there are a few that are especially popular. Three examples are c-myc, a 10-amino-acid segment of the human protooncogene myc (EQKLISEEDL); HA, hemagglutinin protein from human influenza hemagglutinin protein (YPYDVPDYA); and His 6 (six histidines forming a structure that binds the element nickel).

Nontransfected parental cell line (or beads not presenting target of interest)

These serve as the negative control.

Phosphate-buffered saline (PBS) $<\mathrm{R}>$

Secondary and tertiary antibodies (e.g., Alexa 647-conjugated goat anti-mouse IgG; Jackson ImmunoResearch)

From the Antibodies collection, edited by Edward A. Greenfield.

(c) 2018 Cold Spring Harbor Laboratory Press

Cite this protocol as Cold Spring Harb Protoc; doi:10.1101/pdb.prot093781 
Downloaded from http://cshprotocols.cshlp.org/ on April 26, 2023 - Published by

Equipment

Titrate this reagent before use in flow cytometry assays. Be sure to use a reagent that does not recognize mouse IgM antibodies, as generally these are unwanted.

Benchtop centrifuge, refrigerated, equipped with plate holder

Flow cytometer with 96- or 384-well plate reading capability

Considerations for the selection of an appropriate flow cytometry system for a given application are discussed in Topic Introduction: Antibody Screening Using High-Throughput Flow Cytometry (Duensing and Watson 2018).

Multidrop Combi-Reagent Dispenser (Thermo Scientific), or equivalent

Plates, 96- or 384-well, V-bottomed

Water bath, $37^{\circ} \mathrm{C}$

\section{METHOD}

\section{Labeling Negative Cell Line with Cell-Permeant Dye}

1. For each 384- or 96-well plate to be screened, grow $2.5 \times 10^{6}$ cells each of the experimental and control cell lines.

Verify that cell viability is $>95 \%$ before use in an assay.

2. Label the nontransfected parent (i.e., the negative cell line) with a cell-permeant dye.

i. Dilute the stock solution to $1 \mu \mathrm{M}$ in PBS.

ii. Wash the cells to be labeled by centrifugation at $1500 \mathrm{rpm}$ for $1 \mathrm{~min}$ in PBS.

iii. Resuspend the pellet containing $1.0 \times 10^{7}$ cells in $1 \mathrm{~mL}$ of diluted dye. Incubate for $5 \mathrm{~min}$ at $37^{\circ} \mathrm{C}$ in a water bath.

3. Add $5 \mathrm{~mL}$ of FBS to stop the labeling reaction. Wash the cells with FACS buffer by centrifugation at $1500 \mathrm{rpm}$ for $1 \mathrm{~min}$.

4. Mix parent and transfected cell lines together in equal numbers in FACS buffer to a final concentration of $2 \times 10^{6}$ cells $/ \mathrm{mL}$. Use the flow cytometer to confirm that both cell populations can be seen.

\section{Sample Testing}

5. Using a Multidrop Combi-Reagent Dispenser with a stacker for cell addition, aliquot $25 \mu \mathrm{L}$ of cells/well into 96-well plates, or $10 \mu \mathrm{L}$ of cells/well into 384-well plates.

6. Add $25 \mu \mathrm{L}$ of hybridoma supernatant or phage preparation containing antibodies to be tested to every well. Incubate for $60 \mathrm{~min}$ at $4^{\circ} \mathrm{C}$.

7. Wash twice with FACS buffer by centrifugation at $1500 \mathrm{rpm}$ for $1 \mathrm{~min}$. Again, a multidrop can be used for buffer addition.

8. Label the cells with either $25 \mu \mathrm{L}$ of a 1:100-1:500 dilution of Alexa 647-conjugated anti-mouse IgG-specific secondary antibody or $25 \mu \mathrm{L}$ of $1 \mu \mathrm{g} / \mathrm{mL}$ mouse anti-epitope tag. Incubate for $45 \mathrm{~min}$ at $4^{\circ} \mathrm{C}$.

9. Wash the wells twice with FACS buffer by centrifugation at $1500 \mathrm{rpm}$ for $1 \mathrm{~min}$. Proceed to either Step 10 or 11.

10. To screen hybridoma supernatants, resuspend the cell pellets in $50 \mu \mathrm{L}$ of FACS buffer. Proceed to Step 12.

11. To screen phage, add $25 \mu \mathrm{L}$ of a 1:100-1:500 dilution of Alexa 647-conjugated anti-mouse IgGspecific tertiary antibody. Proceed to Step 12.

12. Incubate for $45 \mathrm{~min}$ at $4^{\circ} \mathrm{C}$. 
T.D. Duensing and S.R. Watson
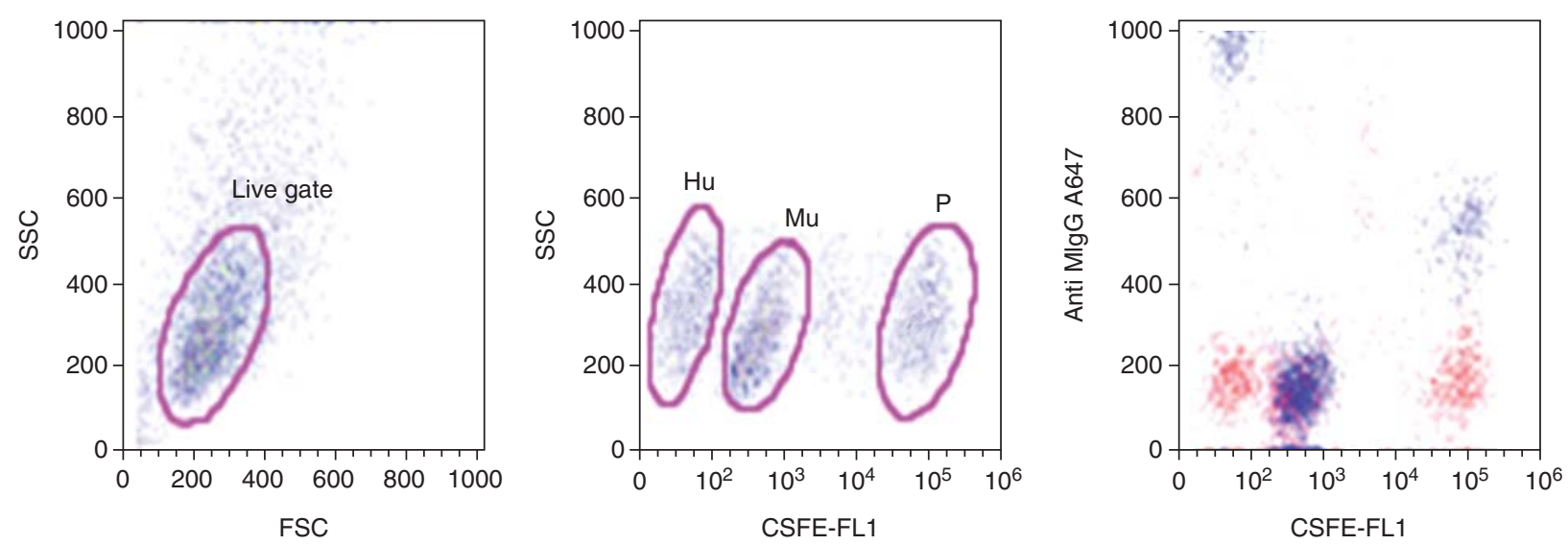

FIGURE 1. Sample gating strategy for determining antibody binding to three different cell populations. (Left) Live cells were separated from noise and debris using an FSC versus SSC scatterplot. (Middle) Three cell populations, each containing a different level of CFSE, were resolved using the CSFE signal. The three cell types are the parental line (P) and lines transfected with a human receptor $(\mathrm{Hu})$ or the murine receptor $(\mathrm{Mu})$. (Right) The three cell populations stained either with a negative control supernatant (red dots) or a test supernatant (blue dots) are overlaid on one another. It can be seen that the test supernatant binds very well to the human cell line, does not bind to the mouse cell line, and shows some binding to the parent line. The median fluorescence intensities are calculated for the binding of the Alexa 647-conjugated anti-mouse IgG to the three populations (data shown in Table 1).

13. Wash the wells twice with FACS buffer by centrifugation at $1500 \mathrm{rpm}$ for $1 \mathrm{~min}$.

14. Resuspend each pellet in $50 \mu \mathrm{L}$ of FACS buffer.

\section{FACS Data Acquisition and Analysis}

15. Set up the flow cytometer such that the two cell populations can be distinguished on the basis of the cell-permeant dye staining.

Collection of 1000 cellular events is generally more than sufficient in screening mode.

16. Analyze the data using the following strategy (an example gating strategy is shown in Fig. 1).

i. Gate in viable cells and singlets as determined by forward and side scatter (FSC and SSC, respectively).

ii. Gate parent and transfected cells as determined by SSC and the fluorescence representing the cell-permeant dye staining.

iii. Determine the mean fluorescence intensity (MFI) for Alexa 647 staining for parent and transfected control cells.

iv. Express the MFI as a ratio of the signal from the target cells to the negative control cells (Table 1). Compare with the signals from the positive and negative control wells on the plate to determine the cutoff.

TABLE 1. Sample results from a hybridoma binding assay

\begin{tabular}{lccccc}
\hline MFI anti-mouse IgG & Negative control & Test antibodies & Positive control & Ratio test/negative control & Ratio positive/negative control \\
\hline P cell line & 200 & 500 & 300 & 2.5 & 1.5 \\
Hu cell line & 200 & 1400 & 1500 & 7 & 7.5 \\
Mu cell line & 200 & 250 & 1750 & 1.25 & 8.75 \\
\hline
\end{tabular}


In the example shown in Figure 1 and summarized in Table 1, the MFI for the test antibodies was high (1400) for the human cell line and low for the murine and parent control cell line. Thus, it can be concluded that the supernatant contains an antibody that primarily recognizes the human form of the receptor and has some nonspecific binding activity on the parent control cell line.

\section{RECIPES}

Fluorescence-Activated Cell Sorting (FACS) Buffer

\begin{tabular}{lcc} 
Reagent & Quantity & Final concentration \\
\hline Bovine serum albumin & $100 \mathrm{mg}$ & $1 \%$ \\
Fetal bovine serum & $100 \mu \mathrm{L}$ & $1 \%$ \\
Sodium azide & $10 \mathrm{mg}$ & $0.1 \%$ \\
Phosphate-buffered saline $\langle\mathrm{R}\rangle$ & to $10 \mathrm{~mL}$ & $1 \times$
\end{tabular}

Phosphate-Buffered Saline (PBS)

\begin{tabular}{lcccc} 
Reagent & $\begin{array}{c}\text { Amount to add } \\
\text { (for } 1 \times \text { solution) }\end{array}$ & $\begin{array}{c}\text { Final } \\
\text { concentration } \\
(1 \times)\end{array}$ & $\begin{array}{c}\text { Amount to add } \\
\text { (for 10× stock) }\end{array}$ & $\begin{array}{c}\text { Final } \\
\text { concentration } \\
(10 \times)\end{array}$ \\
\hline $\mathrm{NaCl}$ & $8 \mathrm{~g}$ & $137 \mathrm{~mm}$ & $80 \mathrm{~g}$ & $1.37 \mathrm{M}$ \\
$\mathrm{KCl}$ & $0.2 \mathrm{~g}$ & $2.7 \mathrm{~mm}$ & $2 \mathrm{~g}$ & $27 \mathrm{~mm}$ \\
$\mathrm{Na}_{2} \mathrm{HPO}_{4}$ & $1.44 \mathrm{~g}$ & $10 \mathrm{~mm}$ & $14.4 \mathrm{~g}$ & $100 \mathrm{~mm}$ \\
$\mathrm{KH}_{2} \mathrm{PO}_{4}$ & $0.24 \mathrm{~g}$ & $1.8 \mathrm{~mm}$ & $2.4 \mathrm{~g}$ & $18 \mathrm{~mm}$
\end{tabular}

If necessary, PBS may be supplemented with the following:

\begin{tabular}{|c|c|c|c|}
\hline $\mathrm{CaCl}_{2} \cdot 2 \mathrm{H}_{2} \mathrm{O}$ & $0.133 \mathrm{~g}$ & $1 \mathrm{mM}$ & $1.33 \mathrm{~g}$ \\
\hline $\mathrm{MgCl}_{2} \cdot 6 \mathrm{H}_{2} \mathrm{O}$ & $0.10 \mathrm{~g}$ & $0.5 \mathrm{~mm}$ & $1.0 \mathrm{~g}$ \\
\hline
\end{tabular}

PBS can be made as a $1 \times$ solution or as a $10 \times$ stock. To prepare $1 \mathrm{~L}$ of either $1 \times$ or $10 \times \mathrm{PBS}$, dissolve the reagents listed above in $800 \mathrm{~mL}$ of $\mathrm{H}_{2} \mathrm{O}$. Adjust the $\mathrm{pH}$ to 7.4 (or 7.2, if required) with $\mathrm{HCl}$, and then add $\mathrm{H}_{2} \mathrm{O}$ to $1 \mathrm{~L}$. Dispense the solution into aliquots and sterilize them by autoclaving for $20 \mathrm{~min}$ at $15 \mathrm{psi}\left(1.05 \mathrm{~kg} / \mathrm{cm}^{2}\right)$ on liquid cycle or by filter sterilization. Store PBS at room temperature.

\section{REFERENCES}

Duensing TD, Watson SR. 2018. Antibody screening using high-throughput flow cytometry. Cold Spring Harb Protoc doi: 10.1101/pdb.top093773. 


\section{Simple Multiplexed Antibody-Binding Assay}

Thomas D. Duensing and Susan R. Watson

Cold Spring Harb Protoc; doi: 10.1101/pdb.prot093781

\begin{tabular}{|c|c|}
\hline $\begin{array}{r}\text { Email Alerting } \\
\text { Service }\end{array}$ & Receive free email alerts when new articles cite this article - click here. \\
\hline $\begin{array}{l}\text { Subject } \\
\text { Categories }\end{array}$ & $\begin{array}{l}\text { Browse articles on similar topics from Cold Spring Harbor Protocols. } \\
\text { Antibodies ( } 119 \text { articles) } \\
\text { Flow Cytometry (42 articles) } \\
\text { Immunoassay ( } 26 \text { articles) } \\
\text { Immunoseparation ( } 31 \text { articles) }\end{array}$ \\
\hline
\end{tabular}

